\title{
Development of Character and Life Skills through Islamic Methods of Teaching Acquired Science Subjects at Islamic International Schools in Malaysia
}

\author{
Manar Eissa \\ Kulliyyah of Education, \\ International Islamic University Malaysia \\ Kuala Lumpur \\ manareissa1210@gmail.com
}

\author{
Madihah Khalid \\ Kulliyyah of Education, \\ International Islamic University Malaysia \\ Kuala Lumpur \\ madihahkhalid@iium.edu.my
}

\begin{abstract}
Islamic schools strive to achieve educational excellence while integrating religious and Islamic values into their curriculum. Yet, what makes an Islamic school really "Islamic" is not just its curriculum content, school personnel and religious values, but also the teaching methods employed by the teachers. For an integrated curriculum, what determines the success of its implementation is the teaching methods--how the shari'ah and the acquired sciences are taught to students. The aim of this paper is to investigate teachers' perspectives of the potential benefits of using Quranic and Prophetic Teaching Methods (QPTMs) in acquired science classes to develop students' character and life skills. This study, which employed semistructured one-on-one interviews, was conducted with six teachers who were teaching acquired science subjects at six International Islamic schools located in Selangor and Kuala Lumpur, Malaysia. The interviews were transcribed and the collected data were analyzed thematically. The findings revealed the teachers believe that QPTMs contribute significantly to the development of positive characteristics in students, such as respecting others, tolerance, openmindedness, accepting of differences, patience, cooperation, and respect for the leader. At the same time, life skills such as communication, teamwork and leadership, as well as students' self-confidence, self-appreciation, creativity, and spiritual aspects were also mentioned by the teachers as having improved. The research reveals the importance of QPTMs in teaching acquired science classes, and accentuates the importance of Muslim nations and schools to propagate their use in the classroom.
\end{abstract}

Keywords: Islamic education, character development, value inculcation, Quranic and prophetic teaching methods, integrated curriculum

\section{INTRODUCTION}

\section{Knowledge and Education in Islam}

In Islam, knowledge is the basis of every human activity and endeavor. That is why the first chapter and verses (Surah Al-Alaq, verses 1-5) of the Holy Qur'an center upon acquiring knowledge and education. Besides the Qur'an, the Prophet's (PBUH) tradition (sunnah) also gives great attention to education. In pure Islamic tradition, the aim of education is to develop human beings in a comprehensive manner, taking into account the intellectual, spiritual and moral development of the person. 
Although Islamic education and secular education share the same goal of developing humans intellectually, socially and physically, Islamic education adds the spiritual and moral components to this development. All of these components should be developed harmoniously without marginalizing any of them. In other words, Islamic education aims to develop the person as a whole, contrary to western education which focuses mainly on intellectual development (Sheikh, 2013). Rayan (2012) clarified that the main objective of education in Islam is to reform and construct human life and develop a balanced relationship between the individual, the society and the world based on ethical concepts. Hence, Islamic education must provide Muslims with the knowledge and moral foundation to perform any task in life. However, since the advent of western education into most Muslim countries, Islamic education has been confronted with several crises that are preventing it from achieving its lofty goals.

One of these crises is dualism. It is a major issue afflicting education in the Muslim world for decades (Al-Faruqi 1982; Hashim 1994). Dualism occurs when education is divided into two opposing factions (Yasin, Firdaus, \& Jani, 2013). On the one hand, there is traditional and conservative education deeply entrenched in concerns about religion and religious subject matter while relegating the acquired sciences to the periphery. On the other hand, there is secular or modern education that prioritizes subject matter--such as science and mathematics-completely over religion and religious concerns. In the Muslim world, secularism results in Islamic studies being marginalized, particularly when Muslims see secular education as being more desirable. This educational dualism has damaged the social and educational lives of Muslim children globally (Omar, 2016). Sheikh (2013) believes that both secular and Islamic education have noticeably failed to produce integrated Islamic personalities. This is evident from the output of educational institutions in both the western and the purported Islamic worlds whose graduates are bereft of the moral uprightness defined by the Islamic code of ethics.

The Muslim and non-Muslim worlds are both facing moral degradation amongst their youth (Ali, 2009) as can be seen in the social environment and the moral problems hitting Muslim and non-Muslim communities everywhere. Thus, in the Muslim world or Muslim ummah at least, there is an increased need to return to an education entrenched in Islamic values and ethics in order to overcome the moral degradation and behavioral disorders affecting the society (Holori, 2013). Educational institutions have to carry on their shoulders the burden of developing students' character by instilling the proper beliefs, morals and values. Hence, many Islamic schools have made efforts to develop an integrated curriculum that inculcates Islamic values into their subjects. The aim of the integrated curriculum is to overcome the secularization of knowledge, and to connect among scientific knowledge, Islamic principles and real-life experiences. The implementation of the integrated curriculum in these Islamic schools requires integrating several elements. Among these elements are beliefs, values and skills that can be inculcated through proper and well-grounded teaching methods. Since the Qur'an and Sunnah are the foundations of all matters related to Muslims theory and practices, the teaching methods should also take into consideration these sources.

\section{Quranic and Prophetic Teaching Methods}

Teaching methods, according to Al-Syaibani (as cited in Kasim \& Tamuri, 2010), are a number of things. They can be (i) channeled activities meant to shape the character of students; or (ii) the design of a learning atmosphere; or (iii) a system that helps learners to gather knowledge; or (iv) the building of morals and behaviors. In the context of this study, teaching methods would mean a conglomerate of these four things. Traditionally, Islam has been using effective teaching methods to produce spirituality in man and to train the Muslim mind to be observant, 
reflective and deliberative. Righteous Muslim predecessors, especially in the first three centuries of Islam, strived to develop the Muslim society according to the basics and principles expounded in the Qur'an and Sunnah. It should be noted that the Prophet Muhammad (PBUH) himself was not only a preacher of a new religion; he was also an effective role model and teacher (Al-Khalediy, 2011) who diversified his teaching methods when engaging with the Muslims. Muslim scholars (the 'Ulamas') used to give lectures in religious subjects--such as interpretations of the Qur'an and the prophetic tradition--as well as in mathematics and the sciences with students gathering around them (Al-Khalediy, 2010). Therefore, the teaching methods used by Muslim scholars are not just peculiar to Islamic studies; they can be implemented in teaching acquired sciences as well.

Quranic teaching methods, theoretically, are grounded in Allah's commandments. Verse 125 of Surah An-Nahl (The Bee) proclaims:

"Invite to the way of your Lord with (hikmah) wisdom and good (hassanah) instruction, and argue with them in a way that is best. Indeed, your Lord is most knowing of who has strayed from His way, and He is most knowing of who is [rightly] guided."

The word hikmah used in the above verse is associated with wisdom, which literally means, putting something in its proper place. In this case, exercising hikmah would mean modifying teaching to suit the learners' level of ability, thinking, and prior knowledge. Meanwhile, the word hassanah (good) is associated with something pleasant, interesting and nice. This means the afore-cited Quranic verse commands us not to be arbitrary in our teaching, but to teach with wisdom that involves deep thought, proper planning and the use of pleasant words. A composite of these elements in teachers' teaching method will ultimately produce positive outcomes. Some teaching methods that have their origin in the Qur'an are: logical illustration, storytelling, the narrative method, dialogue, analogies, metaphors, and parables (Al-Khalediy, 2011; Âşik-ev, 2017). Without mincing words, Quranic teaching methods have been proven versatile and effective in the past and the present for the holistic and moral development of man.

In the same vein, the Prophet's (PBUH) educational approach and methods for moral development were clearly exemplified in his life. Prophetic methods of teaching are practical illustrations of Allah's commandments in the Quran. Narrated by Aisha (RA) from Bukhari (hadith 3375), the Prophet (PBUH) when he spoke would speak clearly, visibly and slowly during his lectures. Jaafar et al. (2017) listed eight prophetic teaching methods, which include: calling people in a respectable manner, speaking about something in general before going to the specifics, delivering lectures clearly, smoothly and completely, using non-verbal communication cues, injecting humor into teaching, and explaining with analogies and comparisons. Other methods mentioned by scholars are: teaching by repetition, narration, dialogue, parables and teaching through practice and application (modeling) (Al-Khalediy, 2011; Âşik-ev, 2017). Hashim (2008) also mentioned several teaching methods used by the Prophet (PBUH) such as lecture, halaqah, drawing, using examples, storytelling, problem solving, demonstration, role modelling, and questioning. These methods were used by the Prophet Muhammad (PBUH) in teaching mankind and had left an impeccable and everlasting impact on the entire humanity, although the Prophet's reign of da'wah only lasted for a short period of 23 years. Arguably, this is enough evidence to support the efficacy of prophetic methods in ensuring character development. Summarily, Quranic and Prophetic methods are established and confirmed means for character uplifting, and have been proven worthy of inclusion and integration in educational systems across the globe. It is, therefore, essential to 
integrate these Islamic teaching methods into the educational systems of not only the Muslim world, but also the western world, based on the current needs for moral education.

\section{Education and Character Development}

Kuh and Umbach (2004) stated that a character is "a window into the personality, a constellation of attitudes, values, ethical considerations, and behavioral patterns that represent what the people believe and value, how they think and what they do" (p. 37). Someone with a character, according to Ali (2009), is a person who demonstrates intellectual and behavioral traits that match societal values and beliefs. Developing individuals with character is the core goal of education in society. From an Islamic perspective, Langgulung (2000) described the human personality as the exhibition of basic beliefs about the purpose of human creation as well as the basic duties of Islam. Meanwhile, the Cambridge Online dictionary defines life skills as "skills that are useful or important in everyone's life."

The goal of teaching is to enhance morals and attitudes (Al Harthy, 2013), in addition to delivering knowledge and skills. Experts concur that the crucial role of schools is to develop students' values and mold their character (Rughubar-Reddy, 2014). Teachers, as key agents in the teaching and learning process, are responsible for the overall development of students--this requires more than just mastering the content. To develop life skills in students, prospective teachers must acquire good proficiency in teaching methods (Razia, 2016). This renders life skills and moral development as part of the major goals of education.

Therefore, in order to achieve the comprehensive goals of education, according to curriculum theorists, the teaching methods teachers employ must have a direct or indirect influence on student outcomes (Motamedi, 2005, as cited in Rizi, Najafipour \& Jafari, 2013). In this regard, teaching methods constitute a major and critical aspect in the inculcation of morals and values in learners (Noormohammed, 2013). Al'Alwani (2005) also suggested that the teaching methods used by teachers, in addition to the curricular content in schools, can be a major source of students' values and attitudes. As such, their use can possibly direct or deviate students away from Islamic conduct. Ampadu (2012) stated that students perceive their teachers as "custodians of knowledge" who shape their learning experiences and influence their actions.

Therefore, what students experience in the classroom will be a source of guidance in the future. Students look at teachers as their role models and tend to imitate them in their behaviors, actions, beliefs, values, and expressions which necessitate the teachers to act morally, calmly and reasonably all of the time (Halabi, 2015). Students can acquire the ways of conveying their thoughts, beliefs and ideas from their teachers. This process of socialization enables them to interact, communicate, convince, discuss, make decisions and solve problems in socially acceptable ways. Thus it is extremely important that teachers employ the right teaching methods as they are significant means of morally educating students in the classroom (Halabi, 2015). In essence, we can conclude that teaching methods are crucial to the moral development of learners.

In lieu of the above, Tauhidi (2001) designed a comprehensive value education (Tarbiyah) program in which he suggested that students would learn better through inculcation (understanding), modeling (seeing), and facilitation (doing). Student understanding is among the many abilities that can be developed through proper education (Tauhidi, 2001). The act of inculcating moral values in teaching means molding students persistently and repeatedly so as 
to implant or instill an idea, theory or attitude into them. The effective inculcation of theories, principles and ideas can lead to a better and deeper conceptualization of the subject matter.

\section{Islamic Schools in Malaysia}

It is justifiably imperative for Malaysia as a Muslim country to adopt Islam in its educational system for its Muslim citizens. The Malaysian National Education Philosophy reflects the need to equip students with knowledge and skills required for life by emphasizing subjects such as science, mathematics and language, in addition to developing the students holistically, intellectually, spiritually, emotionally and physically:

"Education in Malaysia is an ongoing effort towards further developing the potential of individuals in a holistic and integrated manner so as to produce individuals who are intellectually, spiritually, emotionally and physically balanced and harmonious, based on a firm belief in and devotion to God. Such an effort is designed to produce Malaysian citizens who are knowledgeable and competent, who possess high moral standards, and who are responsible and capable of achieving a high level of personal well-being as well as being able to contribute to the betterment of the family, the society and the nation at large”. (Education Act 1996, 2012)

Meanwhile, some private "Islamic schools," like the International Islamic School and Al-Baseerah, integrate Islamic knowledge and values through their academic curriculum. Private Islamic schools aim at inculcating Islamic morals and values to enhance the moral and spiritual development of students. These schools are keen on achieving educational excellence while integrating religious values into their curriculum (Hashim, 1994). Similarly, some Islamic international schools in Malaysia offer the Cambridge international programs and examinations which are among the most popular choices in South East Asia. In order to cater to the academic needs of the students, these schools use British textbooks recommended by the Cambridge program (Souad \& Ramdane, 2014) such as Cambridge, Nelson and Oxford. These books are judged efficient in teaching core academic subjects as they include the key syllabus of each subject (Cambridge Assessment International Education [CAIE], 2014). In addition, these textbooks are designed to meet the needs of all students to enable them to pass the checkpoints and IGCSE (CAIE, 2014). But an issue with the British textbooks is that they have taken a secular stand towards religion. Omar (2016) stated that most of the teaching materials used in international or private for-profit Islamic schools nowadays are produced by western countries due to the western or secular curriculum they follow. Thus, the books do not support the Islamic worldview. In order for the Islamic schools to achieve academic excellence without compromising on Islamic values, they incorporate an Islamic studies component, as well as Qur'an and Arabic Language classes, into the existing secular curriculum.

\section{LITERATURE REVIEW}

Many studies have been conducted on value inculcation in teaching Islamic studies using Islamic instructional methods. Some studies also have explored the importance of inculcating values in teaching "value-free" subjects. Noormohammed (2013), for instance, examined the methods used by teachers in Zanzibar to inculcate moral values in Islamic studies and the consistency of the approaches with those advocated in the Quran and Sunnah. She found that 
the teachers believed that values should be inculcated using Quranic and prophetic methods, and recommended that all teachers be upgraded with new teaching techniques. The Ministry of Education, she further added, should follow up on how effective the teaching methods really are in inculcating moral values. Noormohammed suggested exploring the teaching methods that can instill moral values used in acquired science subjects, such as social sciences, business and economics.

Most teachers are not resistant to inculcating moral values in their teaching. Two studies may be cited to support this claim. The first is Holori (2013), who found that teachers at the International Islamic School in Malaysia are mostly positive towards infusing Islamic values into teaching. The second is Halabi (2015), who found that Mathematics teachers in an Islamic primary school in Malaysia agreed that value inculcation can help nurture positive student behavior and increase their faith, in addition to making maths learning more interesting. Among their recommendations is to include Islamic values, like honesty, respect and trustworthiness, in the school's mathematics curriculum. It is a common misconception that mathematics, as an example of an acquired science, is a value-free subject. Liman and Salleh (2013) examined the applicability of the sociological and mathematical educational values inculcated in a mathematics classroom to the real world. They discovered that the inculcation of values in teaching mathematics enables both teachers and learners to have a holistic view of the subject, and helps them to use the values practically in real world situations.

According to Razia (2016), many lifelong skills--like decision making and problem solving--can be inculcated in students to develop in them the ability to deal constructively with life issues, decisions and problems. Effective communication and interpersonal skills can also be cultivated to enable them to express their beliefs and opinions, and interact with people positively. Razia (2016) highlighted the importance of developing critical and creative thinking as they give students the skills to analyze situations in an objective manner and explore different alternatives to any problem. With these skills, students will have the ability to respond to any situation in their lives. Other life skills mentioned by Razia (2016) include self-awareness, empathy, and coping with emotions and stress. While there is a plethora of studies documenting the myriad methods used to integrate moral values and lifelong skills into Islamic studies and mathematics classes, few have specifically explored how Quranic and prophetic methods can effectively ensure students' moral development in acquired science subjects.

\section{Statement of the Problem}

The ultimate goal of education is to produce individuals who are well-balanced in academic endeavors and high in integrity. Such individuals are better off to contribute positively to society than individuals who are ill-balanced (Lubis, Mustapha \& Lampoh, 2009). Yasin, Firdaus and Jani, (2013) highlighted that Islamic education differs from secular education in its aim to educate human beings. Islamic education incorporates knowledge, skills and ethics approved by the Islamic 'Shari'a, and does not focus purely on acquiring intellectual knowledge. Some Muslim scholars in the USA believe that Muslim students must internalize the principles and beliefs of Islam in their daily lives in order to socialize with modern society (Douglass \& Shaikh, 2004). Islamic institutions have made great efforts in this respect by following the Prophet Muhammad (PBUH) who worked hard with divine guidance to perfect the morals of the Arabs (Ali, 2009).

Muslim parents send their children to Islamic schools to expose them to Islamic studies and the Islamic environment (Halabi, 2015). The exposure to Islamic values and ethics, however, should not be limited to just the Islamic studies classrooms. It should also be extended 
to other subjects. Unfortunately, subjects in the acquired sciences are seen as value-free, and are often taught cognitively without the connections to spirituality. Contrary to popular belief, moral values can be inculcated indirectly in acquired science classes, for the reason that developing students' character and instilling values in them are as important as teaching the students languages, mathematics, science and humanities. The Holy Quran is a rich repertoire of teaching methods which the Prophet Mohammed (PBUH) used to educate early Muslims. Modern day teachers should do the same to develop sound moral character in students. Despite the promise of QPTMs, their potential role and benefits in teaching the acquired sciences is not greatly explored.

The methods of teaching examined in the study are: using parables or metaphors, narrating stories, creating dialogues, repetition of statements or situations, practical applications, gradual teaching, demonstrating, using graphic illustrations, problem solving, and study circles known as "halaqah". The selected methods were chosen in reference to previous studies (Alotaibi, 2014; Noormohamed, 2013; Rustham \& Arifin, 2012; Hamad, 2004). Some of the methods, namely graphic illustrations and gradual teaching, were suggested by Hashim (2014).

\section{Research Objective}

The present study examined teachers' perspectives of the roles and benefits of using Quranic and Prophetic Teaching Methods in teaching acquired science subjects on the development of students' character. The roles and benefits explored were in terms of character development and the life skills students would acquire after having gone through the QPTMs. The study is significant because it suggests a practical contribution to the Islamization of curriculum by considering the QPTMs as innovations in Islamic education, aiming to reduce the secular supremacy of the western educational system. The study can draw the attention of integrated curriculum developers to the impact of including QPTMs in teaching acquired science subjects on developing students' characters and life skills.

\section{METHODOLOGY}

\section{Research Approach}

The researchers used a qualitative approach to explore the roles and potential benefits of QPTMs in molding students' character, and instilling in them moral and spiritual values. Data on the QPTMs were collected via semi-structured one-on-one interviews with the teacher participants, whose answers were recorded and then transcribed verbatim (Creswell, 2012).

\section{Participants}

The teacher participants were selected from six international Islamic secondary schools in Selangor and Kuala Lumpur through purposive sampling. Based on the recommendation of their respective school principals, six teachers--all of whom were female--were chosen as participants based on their experience, knowledge, and verbal fluency. These criteria were important in the teacher selection to ensure that they could provide rich data to address the research objective. The teachers' particulars are shown in Table 1. 
Table 1

The Teachers' Demographic Information

\begin{tabular}{ccccc}
\hline Interviewee & Gender & Degree & $\begin{array}{c}\text { Teaching } \\
\text { Experience }\end{array}$ & Subject \\
\hline Teacher 1(T1) & Female & Bachelor & 5 years & Mathematics \\
Teacher 2 (T2) & Female & Bachelor & 2 years & Science \\
Teacher 3 (T3) & Female & Masters & 4 years & Science and Bahasa Melayu \\
Teacher 4 (T4) & Female & Bachelor & 2 years & Mathematics and Physics \\
Teacher 5 (T5) & Female & Bachelor & 8 years & Humanities \\
Teacher 6 (T6) & Female & Masters & 10 years & English \\
\hline
\end{tabular}

\section{Interview Questions}

The central questions asked in the interviews were: (i) What are the moral values, traits and life skills characters and life skills that can be developed in students by using QPTMs? and (ii) How does the use of QPTMs mold students' character and life skills? From the outcome of the interviews on these questions, a heading and several themes emerged which are highlighted in Table 2.

Table 2

Emergent Themes from the Interviews

\begin{tabular}{lll}
\hline \multicolumn{1}{c}{ Heading } & & \multicolumn{1}{c}{ Themes } \\
\hline Efficacy of QPTMs & 1. & QPTMs develop communication skills \\
in developing & 2. Team spirit is inculcated through QPTMs \\
Positive Characters & 3. QPTMs build leadership skills \\
and Skills & 4. QPTMs improve self-confidence and creativity \\
& 5. QPTMs build spiritual uprightness \\
\hline
\end{tabular}

\section{Procedures}

The interviews were conducted by one of the researchers. She started each session with an introduction to the study's purpose. The teacher participants were told that their identities would be kept strictly confidential. They were also asked to sign a consent form to indicate their approval of the interview and the use of their answers in the research study. The interviews took place at the teachers' choice of time and place. Each session lasted for about 45 minutes. The data collected were later transcribed by converting audiotapes to written words. This stage was followed by a manual analysis where the data were coded and reduced to the barest minimum possible to form themes. The generated themes were later used as findings. 


\section{FINDINGS}

\section{Efficacy of QPTMs in Developing Positive Characters and Life Skills}

The teachers' responses revealed that QPTMs were perceived to contribute positively to the development of positive characteristics in students. Such characteristics are: respecting others, tolerance, open-mindedness, accepting of differences, patience, cooperation, and respect for leaders. At the same time, the improvement of life skills such as communication, team work and leadership were mentioned by the teachers, in addition to other important qualities like self-confidence, self-appreciation, creativity and spirituality. Below are the quotations given by the teachers, highlighted according to each emergent theme:

\section{QPTMs Develop Communication Skills}

It was discovered from the interview analysis that QTPMs, like dialogue, discussion and study circle or halaqah, were able to develop students' communication skills in non-Islamic subject classes. It means the use of QPTMs in these classes create opportunities for classroom discourse and enhances students' ability to voice out their ideas and opinions. This assertion was affirmed when three teachers mentioned communication skills as one of the main capabilities that can be molded through the use of QPTMs, such as dialogue, and how this may be done.

"The QPTMs can develop inter-communication skills as many, if not all of them, require students to communicate with the teacher, and also to communicate with their friends. From there they would learn to listen to others, accept other people's views while at the same time voice out their own concerns as well”. (T1, Mathematics)

T5 (Humanities) supported this view when she mentioned,

"Discussions teach students to voice their opinion and interact effectively with people."

T3 (Science and Bahasa Melayu) also remarked that,

"Tolerance can be developed in students. They can learn to tolerate each other and use proper language with their peers."

Discussions and dialogues allow the exchange of ideas around a certain topic, and simultaneously help to cultivate good character in students, such as showing mutual respect, having tolerance, keeping an open mind, being receptive and accepting of differences, and bearing patience.

\section{Team spirit is inculcated through QPTMs}

It was deduced from the analysis that through QPTMs, team spirit is inculcated in students even in acquired science classes. This theme was generated when two teachers, T2 and T5 respectively, mentioned the following:

'Students' characters develop greatly by using various teaching methods. Some of these methods require the students to work together as a group to complete a certain task. This teaches them the true quality and power of teamwork." (T2, Science) 
"In most of these methods the students work in groups. Therefore, they will learn the value of teamwork." (T5, Humanities)

Through group work, students can appreciate the values of cooperation, respecting the leader, sharing ideas, listening to others, and being responsible to accomplish tasks. These values are essential to building a sound moral character in students.

\section{QPTMs build leadership skills}

Leadership skills were also highlighted by the teachers as one of the major outcomes of QPTMs. It was argued that leadership skills are born as a result of teamwork that is practiced through the use of QPTMs. One of the major leadership skills mentioned in the interview is problem solving. This was stated by $\mathrm{T} 5$ and $\mathrm{T} 4$ respectively:

"QPTMs can instill leadership characteristics in students where the leaders manage to lead a group and the others learn to respect and follow the leader to accomplish a certain task, so the students learn to be responsible. For example, problem solving prepares students for life. They learn to work hard to find solutions and become decision makers. Graphic illustrations also teach them how to analyze things and get conclusions." (T5, Humanities)

"Problem solving encourages students to be positive, or persevere and make changes in the process of problem solving." (T4, Mathematics and Physics)

\section{QPTMs improve self-confidence and creativity}

Other important benefits observed by the teachers were the increase in self-confidence, selfappreciation and creativity. However, how the QPTMs enhanced these characteristics in students were not explicitly mentioned by $\mathrm{T} 1$ and $\mathrm{T} 6$.

"QPTMs can also build up the students' creativity and self-confidence." (T1)

"By using storytelling, teachers can incorporate some Islamic values especially self-appreciation and appreciation of Allah's creation, moreover, it can increase students' creativity." (T3)

"These methods can help students be more confident in their abilities." (T6)

\section{QPTMs Build Spiritual Uprightness}

From the perspective of one teacher (T1), spiritual uprightness could be attained through teachers' use of QPTMs. She explained how this could come about:

"If the teachers inform the students that these methods are derived from Islamic heritage not from the western educational system, this will build up their Islamic identity." (T1) 
Upon the researcher's probe as to how she could make a conclusion such as the above, T1 replied:

"For example, in my subject, many concepts especially in Algebra are given by Muslim mathematicians and helped in engineering, but students thought all these developments are western, therefore, they feel elated and happy when they hear this." [T1]

Having discovered that many concepts in Mathematics actually had their origin in great Muslim minds, students began to realize how Islamic scholarship was once a major source of Western civilization and how it paved the way to modern discoveries. This realization filled them with pride and elation, and helped them to see that as a religion, Islam does not prohibit Muslims from achieving academic excellence and making scientific breakthroughs. Upon this realization, students felt more attached to Islam and wished to be associated or identified with it more frequently.

\section{DISCUSSION}

A major finding from the present study is that teachers believed QPTMs are effective in inculcating positive characteristics, values and life skills in students, which comingle to form good character. This finding emerged from the views of the teachers through the process of deduction by the researchers. Some might argue that such deductions do not lend an empirical basis or justification to the findings as they are just inferences based on ordinary statements made by the teachers. In light of previous research, we argue that this outcome is parallel to that of other studies. For example, Noormohammed (2013) revealed that Islamic studies teachers inculcated moral values in students, while Holori (2013) discovered that Islamic studies teachers had a good propensity to cultivate moral values. Halabi (2015) also agreed that value inculcation can help nurture students' sense of morality and good behavior and increase their faith, in addition to making otherwise mundane lessons more interesting. Meanwhile, Razia (2016) added that, many life skills--such as decision making and problem solving - can be inculcated in students through Islamic method of teaching. These skills are a form of empowerment; they enable students to deal constructively with decisions and problems in their lives without having to depend greatly on others around them. From the evidence cited to support the current findings, it may be concluded that QPTMs are effective in molding positive characters and life skills in students. Take, for example, storytelling which is often used in Qur'an. It is not surprising that storytelling inspires and motivates students to become good and better morally. Lessons that use parables and the narrative method can easily get carried away and have students all excited and inspired. It is this feeling of awe in students-that builds up as a result of teachers' use of QPTMs--that drives them to achieve moral goodness and good character. In addition, QPTMs also enhance classroom participation, inspire students to be individuals of respect and integrity, and develop beneficial life skills. 


\section{CONCLUSION}

Developing students' character is a major goal of Islamic education. Bearing this goal in mind, the study set as its main aim to assess teachers' perspectives of the role and benefits of QPTMs in developing good character in students. The views of teachers reported in this article suggested that these methods can develop many positive traits, values and life skills that prepare students to be successful individuals in life. For instance, QPTMs are perceptibly able to build admirable qualities like respect, tolerance, self-confidence and responsibility. In addition to moral and skills development, the spiritual aspect of students is also developed. In using these methods, the teacher participants connected the content being learned to what Muslim greats had achieved in the past, paving the way to a wonderful discovery of the students' own intellectual heritage as Muslims. There was a huge sense of pride and attachment when they learned that contemporary teaching methods commonly used in the classroom today have actually existed in the Quran and Sunnah more than 1400 years ago--even before they were recognized and used in the West. Following the importance of the outcomes, the present study recommends that the results be utilized by integrated curriculum developers as a basis to incorporate QPTMs into teaching. Particular attention should subsequently be given to the moral conduct that can be cultivated in students by using these methods.

\section{REFERENCES}

Al'Alwani, T. J. (2005). Issues in contemporary Islamic thought. London, England: The International Institute of Islamic Thought.

Al-Faruqi, I. R. (1982). Islamization of knowledge: Problems, principles and prospective. Herndon, V.A.: International Institute of Islamic Thought.

Al Harthy, Z. S. (2013). Guiding a life skills teacher in conducting action research to improve interactive teaching strategies (Unpublished doctoral dissertation). International Islamic University Malaysia, Kuala Lumpur, Malaysia.

Ali, I. (2009). Character strength as a contributor to students' academic engagement and psychological well-being: A model of the effect of Temperance (Unpublished master's thesis). Islamic International University Malaysia, Kuala Lumpur, Malaysia.

Al-Khalediy, K. (2011). Education and methods of teaching in Islam in the era of azZarnooji. al-Manhal, 3(4), 23-60.

Al-Kahledy K., (2010). Education and methods of teaching in Islam in the era of az-Zarnooji. Retrieved from http://www.qsm.ac.il/ArbLanguage/docs/majalla/3+4/eng=2=kalid. pdf.

Alotaibi, S. (2014). Study of Islamic teaching methods in Saudi Arabia (Doctoral dissertation, Bowling Green State University, Ohio, United States). Retrieved from https://etd.ohiolink.edu/pg_10?0::NO:10:P10_ACCESSION_NUM:bgsu1395603595

Ampadu, E. (2012). Students' perceptions of their teachers' teaching of Mathematics: The case of Ghana. International Online Journal of Educational Sciences, 4(2), 351-358. 
Âşik-ev, H. (2017). Learning-teaching methods of the Prophet Muhammad (pbuh). Journal of International Social Research, 10(50), 462-466.

Cambridge Assessment International Education. (2014). New endorsed textbook. Retrieved from https://www.cambridgeinternational.org/news/news-details/view/endorsed text books-for teachers-14oct14/

Creswell, J. W. (2012). Educational research: Planning, conducting, and evaluating quantitative and qualitative research. Boston, MA: Pearson Education.

Douglass, S. L., \& Shaikh, M. A. (2004). Defining Islamic education: Differentiation and applications. Current Issues in Comparative Education, 7(1), 5-18.

Education Act 1996. (2012, January 1). Retrieved from http://www.agc.gov.my/agcportal /uploads/files/Publications/LOM/EN/Act\%20550.pdf

Halabi, Y. (2015). Inculcating Islamic values in teaching Mathematics from teachers and pupils' perspectives: A case study (Master's thesis). Islamic International University Malaysia, Kuala Lumpur, Malaysia.

Hamad, S. (2004). As-salib tadrees al-trbah al-Islamiah al-shaaiah altee uastakhdmha moalmy al-trbaih al-Aslamiah fi al-marhalah al-asahsia alilaafi Gaza wa mbarrat istkhdamaha [The methodology of teaching Islamic education which is used by the teachers of Islamic education in the preparatory stage in Gaza-governorates], Islamic University Magazine (Islamic Studies Series), 12(2), 503-52. Retrieved from

http://www2. iugaza. edu.ps/ar/periodical/articles/volume\%2012-2\%20Issue \%202\% 20-Human\%20-\%2016. pdf

Hashim, C. N. (2014). Issues in values-based education in Malaysia. Kuala Lumpur, Malaysia: IIUM Press.

Hashim R. (1994). Educational dualism in Malaysia: Progress and problems towards integration. Muslim Education Quarterly, 11(3), 34-34.

Holori, M. F. (2013). Teachers' attitude and approaches in the inculcation of Islamic values in teaching: A study of international Islamic school teachers (Unpublished master's thesis). International Islamic University Malaysia, Kuala Lumpur, Malaysia.

Jaafar, N., Muhamad, N. A. F. B., Ghazali, N. B. M., Jamilin, A. K., Kasmani, M. F. Bin, Abdullah, R. B., ... Kanaker, O. (2017). Prophetic communication styles in teaching. Advanced Science Letters, 23(5), 4761-4764. https://doi.org/10.1166/asl.2017.8888

Kasim, A. Y. \& Tamuri, A. H. (2010). Pengetahuan pedagogical kandungan (PPK) pengajaran akidah: Kajian kes guru cemerlang pendidikan Islam [Pedagogical content knowledge (PCK) in aqidah teaching: A case study of excellent Islamic studies teachers]. JIAE: Journal of Islamic and Arabic Education, 2(2), 13-30.

Kuh, G. D., \& Umbach, P. D. (2004). College and character: Insights from the national survey of student engagement. New Directions for Institutional Research, 2004(122), 37-54. 
Langgulung, H. (2000). Islamic education and human resources development in Muslim countries. Muslim Education Quarterly, 18(1), 65-79.

Liman, M. A., \& Salleh, M. J. (2013). Sociological and Mathematics educational values: An intersection of need for effective Mathematics instructional contents delivery. International Journal of Humanities and Social Science, 3(2), 192-203.

Lubis, M. A., Mustapha, R., \& Lampoh, A. A. (2009). Integrated Islamic education in Brunei Darussalam: Philosophical issues and challenges. JIAE: Journal of Islamic and Arabic Education, 1(2), 51-60.

Lubis, S. A. (2012). Islamic education toward the era of social change: Effort in enhancing the quality. Jurnal Al-Tamaddun Bil, 7(1), 107-108.

Noormohammed, H. A. (2013). Methods used by Islamic education teachers to inculcate moral values in Islamic studies: A case study at Lumumba secondary school in Zanzibar, Tanzania (Unpublished master's thesis). International Islamic University Malaysia, Kuala Lumpur, Malaysia.

Omar, F. H. (2016). Influence of dualism on implementation of Islamic integrated curriculum in Muslim pre-schools in Nairobi county (Master's dissertation, University Of Nairobi, Nairobi, Kenya). Retrieved from http://erepository.uonbi.ac.ke /bitstream /handle /11295/97751/ Omar_Influence\% 20Of\%20Dualism\%200n\%20Implementation\%200f\%20Islamic\%20Integrated $\% 20 \mathrm{C}$ urriculum\%20In\%20Muslim\%20Pre-Schools\% 20 In \%20Nairobi\% 20County.pdf? sequence $=1 \&$ isAllowed $=\mathrm{y}$

Rayan, S. (2012). Islamic philosophy of education. International Journal of Humanities and Social Science, 2(19), 150.

Razia, B. (2016). Life skill education: A missing component in teacher education programmes in India. Indian Journal of Applied Research, 6(5).

Rizi, C. E., Najafipour, M., and Jafari, E. M. (2013). The effect of the active teaching method on the academic achievement in the religious concepts. Procedia - Social and Behavioral Sciences, 83, 204-207. doi:10.1016/j.sbspro.2013.06.040

Rughubar-Reddy, S. (2014). Researching values in Mathematical literacy: Trials and impediments. Mediterranean Journal of Social Sciences, 5(23), 1413.

Rustham, N., \& Arifin Mamat, A. A. R. (2012). Teaching methodologies in a weekend madrasah: A study at Jamiyah education centre, Singapore. International Journal of Arts and Commerce (IJAC), 1(2), 148-167.

Souad, M., \& Ramdane, T. (2014). Integrated curriculum success and challenges: A review of the experience of the International Islamic School Malaysia (IISM). The Curriculum of Islamic Education. 
Sheikh, A. S. (2013). Islamic education in Kenya: A case study of Islamic integrated schools in Garissa county (Doctoral dissertation, University of Nairobi, Nairobi, Kenya). Retrieved from https://www.academia.edu/4572149/Islamic_Education_In_Kenya_A _Case_Study_of_Islamic_Integrated_Schools_in_Garissa_County

Tauhidi, D. (2001). The tarbiyah project: An overview. Towards A Renewed Vision of Islamic Education, 8. Retrieved from http://www.voicesempower.com/wp-content/uploads /2015 /11/Tarbiyah-Overview-Dawud-Tauhidi.pdf.

Yasin, F., Firdaus, R., \& Jani, M. (2013). Islamic education the philosophy, aim, and main features. International Journal of Education and Research, 1, 1-18. 